This item was submitted to Loughborough's Research Repository by the author.

Items in Figshare are protected by copyright, with all rights reserved, unless otherwise indicated.

\title{
Monstrous bodies: Theatrical designs by Salvador Dali and Leonor Fini
}

PLEASE CITE THE PUBLISHED VERSION

http://doi.org/10.1386/scp.4.1.9_1

PUBLISHER

Intellect

VERSION

AM (Accepted Manuscript)

PUBLISHER STATEMENT

(c) Rachael Grew, 2019. The definitive, peer reviewed and edited version of this article is published in Studies in Costume and Performance, 4, 1, pp.9-24, 2019, https://doi.org/10.1386/scp.4.1.9_1.

\section{LICENCE}

CC BY-NC-ND 4.0

\section{REPOSITORY RECORD}

Grew, Rachael. 2019. "Monstrous Bodies: Theatrical Designs by Salvador Dali and Leonor Fini". Loughborough University. https://hdl.handle.net/2134/37409. 


\section{Monstrous bodies: Theatrical designs by Salvador Dalí and Leonor Fini}

\section{Rachael Grew}

Loughborough University

\section{Abstract}

Theatrical design is an under-researched area of Surrealist visual culture. This essay examines two examples of Surrealist set and costume design, created by Salvador Dalí and Leonor Fini respectively, through the concept of the monstrous body. Here, 'monstrous' refers to the ambiguous body that defies conventional categories. By using the monstrous body to interpret their designs, this essay will yield a deeper insight into these artists engagement with the Surrealist challenge to rational conventions of individualism. It will also evidence their own interests in fluid, metamorphic bodies that blur boundaries of the normative human and the 'Other'.

\section{Keywords}

Costume, scenography, Surrealism, monstrous, body, Salvador Dalí, Leonor Fini

\section{Introduction}

A core issue for artists engaging with Surrealism was the revolt against the rational, including the Humanist and Enlightenment doctrines of individualism: the notion of a single, complete and static self at the centre of one's identity. Instead, the Surrealists sought to interrogate, fragment, and re-evaluate the issue of identity (Ades et al., 2015: 24). One way in which this rebellion occurred was through the depiction of the body, such as Duchamp's gender-bending alter-ego Rrose Sélavy, or the contortions of the mentally unstable hysteric. This bodily 
rebellion against rational individualism in favour of an unstable, manifold identity can also be found in examples of stage design; a little-discussed aspect of the group's activities.

This essay explores set and costume designs created by two very different artists: Salvador Dalí and Leonor Fini, produced for very different manifestations of Venusberg - the lair of Venus in Wagner's opera Tannhäuser (1861), which opens the opera's action. Dalí used Venusberg as the inspiration for his ballet Bacchanale, performed in 1939, while Fini created designs for Venusberg and its inhabitants as part of a full version of Wagner's opera performed in 1963. As one might expect of Dalí, the costumes for Bacchanale are bizarre, including Lola Montez wearing a Paul Poiret-esque outfit that looks like a skull, fauns with branches sprouting from their heads and lobsters sewn onto their loincloths, the three Graces dressed in revealing, spiky unitards, and the Knight of Death as a folded black umbrella. The action takes place in front of a desert-landscape backdrop dominated by an enormous swan with a cavity in its chest, which functions as the entrance/exit point for some of the dancers notably the characters of Lola Montez, Leda, and Venus. Behind the swan is a mountain that appears to be melting (an example of Dalí's soft structures) and a path leads from behind the swan to a hole at the top of the mountain through which we see a building taken from Raphael's Betrothal of the Virgin (Sharman, 2015:318). ${ }^{1}$

Fini's costumes on the other hand are distinctly aquatic: in addition to the usual fauns (dressed in the typical horns and fur rather than branches and lobsters), we find other dancers dressed in outfits that incorporate scales, fins, and even fish tails. This might seem at odds with an otherwise straight-laced production, using medieval period costume for the rest of the opera, but given that Wagner's original stage directions give the impression of Venusberg as an underwater palace, referring to the presence of a waterfall, a lake, 'coral-like tropical 
vegetation', plus Sirens, Naiads, and Tritons (Wagner, 1988: 61), then it seems fair to say that Fini has not gone completely off-piste for this section of the opera.

There is a steady rise in critical studies on Surrealist theatrical design in general, as well as the designs of Dalí and Fini in particular. Dalí's theatrical designs are discussed most recently in, for example, Elliot H. King et al's Salvador Dali: The Late Work (Atlanta; New Haven: Yale University Press, 2010). Peter Webb's Sphinx: The Life and Art of Leonor Fini (New York: Vendome, 2009), the most substantial scholarly text on Fini in English, discusses Fini's theatrical and fancy-dress costumes as part of a larger, biographical exploration of her oeuvre; they are not analysed in any detail. Indeed, there are no substantial scholarly publications in English dedicated solely to this aspect of Fini's oeuvre. ${ }^{2}$

\section{The monstrous body}

Though the productions are decades apart, and differ greatly in interpretation, they are united by the artists' use of strange hybrid bodies that combine the human and the animal (or fish), and even the animate and the inanimate. Because these bodies do not fit into a single defining category, they become ambiguous; they defy the rational notion of a single, fixed identity. Patricia MacCormack (2012: 79) argues that such ambiguous bodies, which highlight the 'infinite protean configurations of form and flesh' can be viewed as monstrous bodies.

Dalí and Fini's theatrical costume designs are a particularly significant medium for the monstrous body, even more so than their work in other artistic fields, as both artists viewed costume as a catalyst for accessing the ambiguous, manifold self. Dalí (1975) argues that costume constantly acts as a metaphor for the erogenous zones, enabling dress to act as a means of psychoanalytic interrogation. Costume and the act of dressing up therefore reveals 
unknown sides of the fragmented, neurotic self, hidden from the conscious mind. Similarly, Fini also views the act of costuming, of dressing up, as a creative act which reveals multiple sides of the self. When one dresses up one is able to experience being both one's conscious self and someone else (or another, perhaps unconscious self) simultaneously (Fini, 1984: 31). Thus, for both Dalí and Fini, costume is imbued with the potential to deconstruct a single identity into multiple, simultaneous facets. Moreover, their costume designs can be read as creating new, strange bodies for the dancers, producing a monstrous self that is experienced through the body. The concepts evoked through these costumes may potentially encourage the audience reflect on the nature of their body, as we will see. Thus, the theatrical setting engenders a relationship between the 'normative' bodies in the audience and the monstrous bodies on stage, further enabling an opportunity to critique the 'normative' self.

There are still further layers of affinity between the monstrous body and these designs, emphasising it's use as a theoretical lens through which we can analyse the costumes. Firstly, the monstrous, ambiguous body might initially suggest a strong link to Surrealism, given the movement's aim of combining opposites into a new unity. However, both Dalí and Fini had a complex relationship with Surrealism. By 1939, Dalí's indifference to politics, adoption of classical motifs, and courtship of wealthy patrons had led him to be excommunicated from the group, while Fini had always been on its fringes; sympathising with its interest in the dream but unwilling to become a member and place herself under André Breton's jurisdiction (Ades, 1982: 96). Both artists frequently depicted bodies that blurred borders between human, animal, vegetal, and mineral in their painting, creating monstrous hybrids. For Dalí this was to emphasise the irrational, neurotic unconscious and the dominance of the imaginary above the real (another point of conflict with the Surrealists) (Ades, 1982: 98-99). Fini however uses such bodies to effect transformation: the central theme across her oeuvre. 
In both cases therefore, the monstrous body is used to destabilise rational individualism in favour of a constantly shifting, manifold identity.

The use of the monstrous body is also significant within a theatrical context. After the First World War, avant-garde theatre in France was spear-headed by Dadaist and Surrealist productions, which sought to rebel against social conventions like the patriarchal family and the urban middle-class, and, we may add, rational individualism (Guérin, 2007: 252). The monstrous body is thus an excellent vehicle for such rebellion. Though Fini's designs were created for a production performed in the post-modern era, she rejected the post-modern emphasis on dissonance and juxtaposition (Aronson [1991], 2010: 146), preferring traditional historical accuracy, or at least remaining true to the spirit of the production. For Fini, theatre was an immersive, transformative experience, and the monstrous body again supports this focus on transformation and change (Fini, 1975: 41).

Costume is integral to facilitating such change. With its ability to change the appearance, texture, shape, and borders of the body of the wearer, costume is a key agent in enacting an uncanny monstrosity. MacCormack (2012) argues that the changeable ambiguity of the monstrous body simultaneously evokes fascination and horror in the viewer, encouraging a sense of 'in-betweenness' and enabling them to experience this monstrous multiplicity. Such concurrent repulsion and attraction allies the monstrous with the uncanny: the familiar made strange and unfamiliar. The feelings of uncertainty aroused by the uncanny can cause us to question our perception of inner/outer, where the borders lie; even our very sense of self (Royle, 2003: 1-2). The unstable selfhood evoked through the uncanny destabilises the rational notion of a complete, closed, static body, and is thus allied to the ambiguous, monstrous body. Therefore, a costume that makes a familiar human body become strange can 
be the focal point of a viewer's simultaneous attraction and repulsion and therefore acts as the catalyst for the creation of an ambiguous monstrous body. Moreover, as this focal point, costume can also drive an oscillation between boundaries. By creating an unfamiliar image of the human body, it switches between the normative and the Other, refusing binary positions. Rosa Braidotti (2013) has noted that the closed, rational individual of Humanism is rooted in the normative image of the white, Western, healthy, and able-bodied man. As the inverted image of the rational, masculine 'norm', the monstrous body can be viewed as a feminine Other. However, the monster's refutation of binaries, it's ambiguity, is only successful if it constantly oscillates between different positions - if it is only ever Other then it simply reinscribes cultural binaries by providing the negative pole against which bodies can be judged.

Ultimately then, the monstrous body evoked through costume signifies a fluctuating, ambiguous identity at odds with the traditional conception of an individual, static self. It is allied to a feminine, liminal state of being, which can be shared by spectators of the monstrous body. Given Dalí and Fini's interests in ambiguity and transformation, it can directly map onto their real-life and artistic creations.

Wagner, costume, and monstrosity

Using the monstrous body as the focus for this analysis becomes even more relevant when we consider that both artists link Wagner - the source of their productions - with ambiguity; the core element of monstrosity. Dalí's knowledge of Tannhäuser is revealed through archival documents, which outline Wagner's conception for the set design of Venusberg, and the action of the bacchantic ballet (Dalí, c. 1939, c. 1939-41). This familiarity is further revealed in Dalí's notes for the ballet programme, which illuminates how he merges Wagner with his own aesthetic interests: 
My brain and my eyes have always been attracted by mountains. And of all mountains, it was Wagner who produced the greatest effect on me. . If Wagner is the most difficult mountain to be observed distinctly, not only due to the lyric vapour in which he so often drowns, but also because of his non prehensile morphology, the contours of Venusberg, one of the last mountains ascended by Wagner. . are much more difficult to delimit (Time, 1939: 62).

Not only is Wagner linked to Dalí's soft-structure mountains (discussed in more detail later), but he becomes manifold: Wagner is Tannhäuser, who ascends Venusberg, who becomes Ludwig II of Bavaria in Dalí's ballet. Wagner is also allied with Dalí given that both of them (according to the latter) use soft, 'non prehensile' structures.

Equally, Leonor Fini viewed Wagner as 'extremely current, with his torn ambiguity, his expression of unconscious desires, his sublimated will always doomed to failure' (Fini, undated: 1). It seems that Fini viewed Wagner in a similar manner to Dalí: both of them ally him with the unconscious and ambiguity.

\section{Manifestations of Venusberg}

Venusberg opens the action of Wagner's Tannhäuser. The eponymous hero has fled from the physical world to the sensual realm of Venus, but now grows frustrated and wishes to return home again. Having escaped Venus' clutches, Tannhäuser finds himself back in the realm of the Landgrave, who rules from Castle Wartburg. He meets the Landgrave and his minstrels hunting; they joyfully welcome him home and they all return to Wartburg where Tannhäuser is reunited with the Landgrave's daughter Elisabeth, whom he loves. The Landgrave then holds a song contest, challenging his minstrels to sing of love. Wolfram, Tannhäuser's friend, 
goes first and sings of chaste, spiritual love. Tannhäuser, however, sings of physical love and Venusberg, much to the horror of the assembly. Elisabeth defends Tannhäuser and, humbled, he vows to go to Rome to repent. On Tannhäuser's return we discover that the Pope has decreed Tannhäuser will only be forgiven when the Papal staff bursts into flower. Overcome by despair, Tannhäuser is tempted to return to Venusberg but is saved from this fate when Wolfram calls out Elisabeth's name, reminding him of his true love. However, Elisabeth has died in Tannhäuser's absence, and he likewise expires over her body, just as we learn from some pilgrims that the Papal staff has flowered, saving his soul.

It is the opening ballet of Act I that provides the foundation for Dali's 1939 ballet Bacchanale, choreographed by Leonide Massine for the Ballets Russes de Monte-Carlo. Having been postponed by the outbreak of the Second World War, Bacchanale finally opened as part of a triple bill on November 9, 1939 at the Metropolitan Opera House in New York (See Norton, 2004: 232-45, Anderson, 1981: 34-38, Sharman, 2005: 316-18). Dalí not only designed the ballet's set and costumes (the latter originally in collaboration with Coco Chanel, who later abandoned the project), but also provided the scenario, pushing his engagement with the theatre further than any other Surrealist up to this point (Crosby, 1939, Norton, 2004: 232). The action transposes the hedonistic ballet into the fevered imaginings of Ludwig II of Bavaria, who "'lived” all of Wagner's myths with such profound visual hyperesthesia as to verge on madness', and replaces Tannhäuser as the protagonist (Dalí, undated, Anderson, 1981: 36, Norton, 2004: 239). The unusual costumes worn by the rest of the cast can therefore be thought of as part and parcel of Ludwig's hallucinogenic visions.

In contrast to Dalí, Fini produced medieval-period costumes and sets for a full production of Wagner's opera, staged by the Opéra de Paris in 1963. Fini (undated: 2) viewed 'avant-garde' 
opera design as 'pretentious [and] annoying', and critics certainly seem to have reacted favourably to her designs, referring to her as 'an ideal interpreter of Wagnerian thought' and her designs as 'some of the finest in the Opéra repertory' (Unknown magazine, Leonor Fini Archive, The Times, 1965). As such, it does not seem that the fish-human hybrids that populate Fini's Venusberg were thought of as being out of place; they encapsulate the 'Other' state of Venusberg just as Dalí's bizarre creations encapsulate Ludwig's mental state.

\section{Erasing, conflating, and fragmenting the body}

In exploring the productions, it seems that different types of monstrous bodies are created by the two artists. Dalí's costumed bodies are predominantly made monstrous through erasing the body, whereas most of Fini's monsters retain their human form but change its constituent materials - from skin to scales and fur. In other words, Fini metamorphoses the borders of her bodies so that they become non-human, whereas Dalí removes (or dramatically alters) them, akin to his soft sculptures. There are exceptions to this on both sides, but these dominant trends produce different readings of the monstrous body. On the one hand, erasure suggests the unformed - an amorphous mass that has the potential to adopt MacCormack's 'infinite protean configurations' of the body. However, it also suggests lack; a disappearance of the body that removes the physical locus of identity and impacts the ability of the audience to identify with the monster presented on stage. The metamorphic body instead highlights a moment in the constant process of transformation that directly connects with MacCormack's equation of shape-shifting with monstrous ambiguity but also retains that physical locus of identity. Alternatively, we also see examples that merge these approaches: one body might be partially erased through a metamorphic fusion with multiple other bodies. 
Ironically, Dalí's Ludwig, despite his highly disordered mind, has perhaps the most normative costumed body, using signifiers that replicate traditional symbols of royalty - such as ermine fur. Ludwig represents an ambiguity of mind rather than body. When Ludwig first appears in the ballet, he imagines himself as Tannhäuser and approaches Venus, but she is rushed offstage by a parade of strange creatures. Ludwig's royal garments are swapped for a monk's habit, mirroring Tannhäuser's shift from nobleman to pilgrim. This is not the only transformation Ludwig undergoes. During the main orgiastic dance of the ballet, Ludwig imagines himself as Lohengrin, another of Wagner's heroes, and attacks Venus. The LudwigLohengrin identity is strengthened by Dalí's use of an enormous swan as the central element of his set design, which we may also interpret in relation to Wagner's 1850 opera Lohengrin. In this opera Lohengrin is ferried from the castle of the Holy Grail to the damsel he has promised to protect by a swan, who turns out to be an enchanted child intended to be the kingdom's ruler (Newman, 1949: 112-13). Thus, the swan acts as the vehicle for moving between states; a catalyst for the fluctuation of bodily identity.

It has also been argued that Tannhäuser (or Ludwig in this case) is representative of the artist, which here could be Dalí and / or Wagner (Ashman, 1988: 10). Thus, his identity is contingent on the interaction of at least four figures: Ludwig, Tannhäuser, Lohengrin, Dalí, and possibly also Wagner, which would make sense given Ludwig II's love of the composer (Blunt, 1970: 7-8). As such, the physically normative body of Ludwig is rendered ambiguous through a monstrous hybrid of embodied selves, erasing the borders between different identities.

This monstrous erasure is also enacted through the crutch. Reflecting on Bacchanale, Dalí (1942: 379) noted: 'I got along very well with Leonid [sic] Massine...it was precisely he who 
was predestined to do the choreography of the Dance of the Crutches'. The Dance of the Crutches specifically refers to the end of the ballet when a dying Ludwig dances with Venus while a satyr and a nymph are propped up with crutches in different poses. Ludwig, the satyr and the nymph are all 'unfixed' - Ludwig because he occupies a liminal space between life and death, and the hybrid characters because they are constantly being repositioned, but it is the crutch itself that signifies in-betweenness, and thus an erasure of borders that implies monstrous ambiguity.

According to Dalí, the crutch became integral to his childhood erotic fantasies after finding one in the house of a family friend, though they only appear in his art from roughly 1932 (Ades, 2005: 430-31). Dalí also uses the crutch as symbolic of a desire to shore up the decaying European aristocracy; this would include Ludwig II, especially considering the mental ill-health on both sides on his family (Ades, 2005: 431, Blunt, 1970: 11-12). The crutch as a symbol of in-betweeness is suggested by Ingrid Schaffner. In describing the Dream of Venus pavilion, a fun house created by Dalí for the 1939 World's Fair, which uses similar imagery to Bacchanale, Schaffner (2002: 112) writes of: 'arms and crutches propping the entire building against the crush of the void. One brittle crutch supports a pendulous blob atop the pediment. The incipient snap latent in this image represented for Dalí a sensation of falling, which he associated with both sleep (casually slipping into an unconscious dream state) and birth (being dropped into reality)'. Hence, the crutch functions as a symbol of inbetweenness, defying a static meaning and category.

Another set of bodies that enact a monstrous erasure of borders are the central female figures in both Dalí and Fini's designs. The trio of Lola Montez, Venus, and Leda from Bacchanale can be viewed as an amalgamated entity. We firstly see this through the stage action - their 
entrances all take place through or around the central swan: the monumental façade of an opening set in the soft structure mountain that dominates the backdrop. Dalí's use of soft structures reflects his interests in morphology, notably Eduoard Monod-Herzen's 1927 study which argues that a living thing was subject to infinite forces and pressures; therefore, it did not simply have one shape, but an infinite number of shapes. Moreover, different entities could share similar shapes if subject to similar forces (Mundy, 2005: 460). Given the connection between the soft structure mountain and the three women, Montez, Leda, and Venus could be one entity in a series of different shapes, or different entities sharing an approximately similar shape - that of Woman.

The conflation of bodies also has an effect on cultural boundaries represented by these bodies. It is significant that Venus, Leda, and Lola Montez appear hard on each other's heels towards the end of the Bacchanale: Venus and Leda appear at the same time while Ludwig dies, only to be replaced by Montez. Their overlapping presences augment their shared connection to the swan, heightening the connection and possible integration of their bodies. This seems even more likely given that all three are personifications of love, lust, and sex, and suggests that Dalí's female bodies are specifically connected with the sexual temptress a dangerous (and thus monstrous) body.

The ambiguous, overlapping trio is present more covertly in Fini's conception of Venus, whom she sees as one facet of a larger female entity:

All my sympathy goes to Venus who is not only sensuality but the dream of a spontaneous, immediate life, yet I believe that she is associated with Elizabeth and the Virgin only as another face. . . It is this primordial identity in 
opposition which tempted me when Georges Auric suggested to me that I design for Tannhäuser (Fini, undated: 1).

Figure 1: Photograph of the crown made for Elizabeth, c. 1963, collection of Le Bibliothèque de la Musée de l'Opéra, Paris. Photograph supplied by Bibliothèque Nationale de France (BnF). (C) Estate of Leonor Fini, Paris.

That Venus, Elizabeth, and the Virgin present three sides of a triangle perhaps echoes Dalí's conflation of Montez, Venus, and Leda, but whereas Dalí's female trio embody sexuality, Fini's embodies creativity. Fini's conception of her female figures is evidenced in her designs. Elizabeth's crown is topped by Christian crosses, suggesting purity. By contrast, bright gauzy material escapes from the plant-like spires of Venus' crown, implying both a lack of restraint and fruitfulness. Meanwhile, the Virgin is not conceived as a chaste figure that is Elizabeth's role here - instead Fini (undated: 2) makes the statue of the Virgin convey a woman 'who will not be gentle but above all punitive, quite terrifying'. We could view these women as a kind of triparte goddess; Elizabeth as chaste Maiden, Venus as fertile Mother, and the Virgin as the authoritative Crone. This reading, however, is complicated by the fact that Elizabeth's crown also includes small pine cones, similarly suggesting fruitfulness. Furthermore, Fini (undated: 2) describes the Virgin as the expression of Tannhäuser's (and Wagner's) subconscious, perhaps making her a phallic mother; the original authority figure repressed in the unconscious. In this way both Elizabeth and the Virgin have at least the potential to occupy the position of fruitful mother, demonstrating a fluctuating triple identity. It seems that the female trios in both sets of designs enact an unstable identity. However, while Dalí's trio can be interpreted as manifestations of a single, abstracted concept (sexual, earthly love), Fini's three female figures may portray a broader 
notion of Woman that moves beyond the negative, Other incarnation of femininity, emphasising complexity and ambiguity of character. In this sense, Fini's monsters are more successful in their subversion of female gendered norms as they oscillate between positions, rather than emphasising a negative Other.

Fig. 2: Leonor Fini: Set design for Venusberg, c. 1963, collection of Le Bibliothèque de la Musée de l'Opéra, Paris. Photograph supplied by Bibliothèque Nationale de France (BnF). (C) Estate of Leonor Fini, Paris.

The erasure of borders between entities, suggestive of a monstrous amalgam, is also present through Fini's set design, if one considers it in relation to her contemporary painting practice. ${ }^{3}$ The jewel-like colours of Fini's Venusberg - red, golden yellow, and turquoise combined with the textured nature of the painted designs suggest a link to Fini's mineral paintings; a series of works from the 1950s and 60s that used similar textured effects and colours. In these paintings, ethereal figures emerge from their surroundings, as though they were inextricably part of their environs rather than separate individuals, creating a humanmineral hybrid.

Figure 3: Seymour Studios: Photograph of Chris Volkov as the Knight of Death, c. 1939. Jerome Robbins Dance Division, The New York Public Library for the Performing Arts. Photo by Maurice Seymour courtesy of Ronald Seymour.

Now let's turn to some more overtly monstrous bodies. The costume of Dalís Knight of Death - a mobile black umbrella - goes even further in the creation of the monstrous body, as it dissolves distinctions between body and inanimate objects. The body and head of the 
dancer are enclosed in the umbrella; the latter is visually relocated as a skull on top of the umbrella's handle. Though the human body has effectively been erased, the bland features of the skull present the Knight of Death as a somewhat universal figure, embodying all humanity. The audience member contemplating the Knight as a symbol of both Ludwig's and their own mortality, is also forced to consider the erasure of their own body and the possibility of other corporeal forms, thereby breaking down the central position of the individual physical body and its traditional borders of clothing and skin.

The sharp, penetrative form of the Knight's body is contrasted with the umbrellas which sedately open and pour onstage as Ludwig dies. The very act of opening suggests erasure as the folds which make up the Knight's body are peeled away, leaving only the central column of the handle; as though both the Knight and Ludwig's corporeal selves are dissolving. This erasure allows us to contemplate a more fluid, free-floating existence, beyond positive / negative conceptions of the body and identity.

The erasure / multiplication of self is enacted in the opposite manner in the figure of the flower-headed woman. In Dalí's designs this character appears to be of indeterminate gender, but we may tentatively define her as female given the presence of similar, clearly female figures in both the Ardent Couch tableaux in the Dream of Venus pavilion, and painted works such as Three Young Surrealist Women Holding in their Arms the Skins of an Orchestra, 1936. The flower-headed woman reinforces the corporeal nature of the body through having had her head removed; stressing physicality through the lack of a mental, spiritual component signified by the head. This is heightened through the head's typical associations with intellect and the rational - without the mind one becomes mere matter. Thus, unlike the Knight's erasure of physical self, the flower-headed woman represents the removal of the sense of self, 
again inviting meditation on non-normative, monstrous (disembodied/insane) conceptions of identity.

\section{Metamorphosing the body}

While most of Fini's monstrous characters also appear as fish-human hybrids, their monstrosity lies not in erasing self but in changing the constituent materials of the body, and depicting it actively transforming. One particularly interesting design depicts the dancer lifting a fish tail in each hand, as though they were sections of a skirt, to reveal the dancer's legs below, suggesting a body in mid-transformation.

This emphasises the liminal nature of the monstrous body as that which hovers on the borders of defined categories as it is the skin, the border of the body itself, which is made non-human. Thus, Dalí's extreme designs and Fini's use of textiles arguably have the same effect: encouraging contemplation of alternative bodies. In both cases the normative corporeal nature of the body is challenged. For example, Roger Pic's photographs of the performance show the fish-human costumes of some of the female dancers are augmented with threedimensional embellishments (beading perhaps?) that enhance the textured surface of the dancers' bodies, placing them at odds with the smooth skin of the normative body. Another example is the costume for the 'scaly man', which is made up of small, overlapping holographic plates, resulting in a look very similar to fish scales. The head piece is similarly made from holographic slivers. The stage lights would have undoubtedly been reflected off the material to create a dazzling effect - again completely alien to the abilities of human skin. A similar effect is created through another of Fini's designs - this time for a Faun. The torso of the Faun is decorated with glittering gold discs. Though this could be some type of necklace, the way in which gold glitter also appears on his furred legs and his horns suggests 
that, once again, this glitter is actually part and parcel of his body. Even when not using embellishments or special materials, an Other skin is generated for the dancers through the mottled patterning of the textile, as we also see in Pic's photographs of the male dancers.

Figure 4: Leonor Fini: Sketch for a 'Scaly man', c. 1963, collection of Le Bibliothèque de la Musée de l'Opéra, Paris. Photograph supplied by Bibliothèque Nationale de France (BnF). (C) Estate of Leonor Fini, Paris.

Figure 5: Leonor Fini: Sketch for female dancer, c. 1963, collection of Le Bibliothèque de la Musée de l'Opéra, Paris. Photograph supplied by Bibliothèque Nationale de France (BnF). (C) Estate of Leonor Fini, Paris.

These various ways of making a monstrous body seem odd given that these creatures are supposed to inhabit the realm of Venus, where sensual pleasure is paramount. It seems paradoxical to expect the audience to believe and lose themselves in this erotic scene when that eroticism is enacted by bodies that invite repulsion, or at least confusion, through their Other nature. This barrier is enforced by subverting sexual expectations. Some of Fini's costume designs for female dancers include additional fins situated at their pudenda, cutting off sexual access while at the same time drawing attention to the site. We are being encouraged to consider the erotic nature of these creatures while concurrently noticing their inhuman differences. This again matches with the concept of the monstrous body as inviting both fascination and fear in the spectator, combining opposing states, and escaping any clearcut definition as to its nature to refute a rationalist identity. Again, Fini's monsters enact an oscillation between states, one which encourages the audience to reflect on their own body and their responses to Other bodies. 
Despite the corporeal erasure we frequently see in Dalí's designs, there is one particular example in which monstrosity is created through addition; the same technique used by Fini for the same character: the Graces. Dalí's costumes for the Three Graces contrast to both the Knight of Death and the flower-headed woman in their engagement with identity. While the monstrous bodies of the Knight and the flower-headed woman use forms of erasure to suggest a manifold, irrational self, the Graces achieve this through the addition of superfluous appendages. The spiky, knife-like protrusions that cover the Graces imply violence, perhaps castration, granting the Graces a femme-fatale identity at odds with their usual associations of fertility, merging feminine personas but ultimately still locating them within a positive / negative binary of femininity. However, some of Dalí's designs for the Graces also depict one of the spikes jutting out at crotch level like an erect phallus, blurring gender borders. Furthermore, in the same drawings, the Grace's many protrusions are supported by crutches, which, if we continue to interpret the crutch as a symbol of in-betweeness, highlight the fluid nature of the Grace's identity. Though this suggests a greater degree of monstrous oscillation than some of his other designs, it still relies on the dangerous, castrating female body.

The concurrent fertility and destruction of Dalí's Graces is also present in at least one of Fini's Graces. I have been able to only find a clear image of one dancer I believe to be a Grace among Fini's designs and photographs of the opera, yet this Grace is an excellent example of blurring boundaries of identity through the body. Rather than referencing violence and castration through a spiky costume, the design of Fini's Grace's costume replicates the patterns that cover Gustave Moreau's Tattooed Salomé of 1876; a woman who traditionally exemplified the castrating femme fatale. Moreau was known to the Surrealists and was especially admired by André Breton. McCormack (2012: 19) quotes Deleuze and 
Guattari who state that "paintings, tattoos, or marks on the skin embrace the multidimensionality of bodies," and she argues that such bodies "allow us to rethink bodies and their pleated surfaces”. So, while the Grace's connection with Salomé creates a similar blurring to Dalí's spiky Graces, her tattoos emphasise the potential fluidity of the body and identity.

\section{Conclusion}

By considering costume as a method of creating the monstrous body, it becomes more of an active force; challenging corporeal norms rather than simply being a decorative covering for a normative human body. The shifts in bodily textures, materials, shapes, borders, and meanings produced by these costumes create ambiguous, changeable, and uncanny bodies that encourage different readings not only of the performing body but also of the audience member's body.

Using the lens of the monstrous body, we can see the ways that Dalí and Fini's designs work to destabilise rational individualism in favour of a fluid self. However, the monstrous body is evoked in different ways through their work: the effect produced by Fini's designs is that the materials of the body are metamorphosed, while that of Dalís is the erasure of the body. Equally, if the monstrous body is gendered as female, then both sets of designs produce different readings of the female body. We could argue that Dalí can be read as enacting a mind / body split, erasing the frightening female body in favour of returning to the (male) mental, specifically the uterine or unconscious mind state. We see this, for example, in the death iconography used in relation to the body of the sexual temptress Montez, and his constant use of the crutch motif. By contrast, I argue that Fini's metamorphic bodies emphasise their physical matter, thus celebrating the (female) creative body, but also oscillate 
between different positions more effectively than Dalís, which tend to emphasise sexual, castrating archetypes. As such, when read through the monstrous body, though both sets of designs produce ambiguous, multiple identities, it seems that Fini's are more effective in questioning the limits of the human, and the rational borders of the self, and embrace a more complex reading of Woman.

\section{References}

Ades, D. (2005) 'Crutches' in Ades, D. (ed.) Dalí: The Centenary. London: Thames and Hudson, pp. 430-31.

Ades, D. (1982) Dalí. London: Thames and Hudson.

Ades, D., Richardson, M., and Fijalkowski, K. (ed.) (2015) The Surrealism Reader: An Anthology of Ideas. London: Tate Publishing.

Anderson, J. (1981) The One and Only: The Ballets Russes de Monte-Carlo. London: Dance Books Ltd.

Aronson, A., 'Postmodern Design' in Collins, J. and Nisbet, A. (ed.s) Theatre and Performance Design: A Reader in Scenography. Abingdon; New York: Routledge, pp. 14553.

Ashman, M. (1988) ‘Tannhäuser - An Obsession’ in Wagner, R., John, N. (ed.) Tannhäuser, Opera Guide Series number 39. London: John Calder; New York: Riverrun Press, English National Opera and Royal Opera, pp. 7-15.

Blunt, W. (1970) The Dream King: Ludwig II of Bavaria. New York: The Viking Press. Braidotti, R. (2013) The Posthuman. Cambridge: Polity Press.

Crosby, J. (1939) ‘The Story of Forty-Five Minutes Delay', Women's Wear, (November 14, 1939), n. p. 
Dalí, S. (undated) 'Bacchanale', typescript copy of programme notes for Ballet RusseMonte Carlo: Season 1939-1940, New York Public Library for the Performing Arts, New York.

Dalí, S. (1975) 'L’erotisme dans le costume', hand-written manuscript, Fundaciò GalaSalvador Dalí: Centre d'Estudis Dalínians, Figueres, document number 38989.

Dalí, S. (c.1939) Untitled typescript [“Du fond de...”], Fundaciò Gala-Salvador Dalí: Centre d’Estudis Dalínians, Figueres, document number 38593.

Dalí, S. (1942) The Secret Life of Salvador Dalí. Translated by Haakon M. Chevalier. London: Vision Press, 1961.

Dalí, S. (c.1939-41) ‘Tannhaeuser’, typescript, Fundació Gala-Salvador Dalí: Centre d'Estudis Dalínians, Figueres, document number 38749.

Davenio, J. (1984) 'Narration as Drama: Wagner's Early Revisions of Tannhäuser and their Relation to the Roma Narrative' College Music Symposium 24: pp. 55-68.

Ettinger, B. (2006) The Matrixial Borderspace. Minneapolis: University of Minnesota Press. Fernández, L. J. (2005) 'Salvador Dalí’. Translated by Marianne Millon in Land, P. (ed.) Richard Wagner: Visions d'Artistes d'Auguste Renoir à Anselm Kiefer. Paris: Sornogy éditions d'art; Genève: Musées d'art et d'histoire, pp. 186-88 [Exhibition catalogue] Fini, L. (undated) 'Leonor on Wagner' Typescript with handwritten title (not Fini's writing), Leonor Fini Archive, Paris.

Fini, L. (1975) Le Livre de Leonor Fini. Lausanne: La Guilde du Livre et Les Éditions Clairefontaine; Paris: Vilo.

Leonor Fini, 'Mes Théâtres', Corps Écrit 10 1984: pp. 31-33.

Guérin, J. (2007) Le théâtre en France de 1914 à 1950. Paris: Honoré Champion. Kingallen, D. (1939) 'The Voice of Broadway', Telegraph, (20 November), n. p. 
MacCormack, P. (2012) Posthuman Ethics: Embodiment and Cultural Theory. Farnham: Ashgate.

Mathieu, P.-L. (2012) Salvador Dalí, Gustave Moreau, André Breton. Paris: ACR Édition. Mundy, J. (2005) 'Soft Structures' in Ades, D. (ed.) Dali: The Centenary. London: Thames and Hudson, p. 460.

Newman, E. (1949) The Wagner Operas. Princeton: Princeton University Press.

Norton, L. (2004) Leonide Massine and the $20^{\text {th }}$ Century Ballet. Jefferson; London:

McFarland and Co. Inc.

'Our Special Correspondent' (1965) 'Tannhäuser in a Fine Setting', The Times, (10 June), n.

p.

Royle, N. (2003) The Uncanny. Manchester: Manchester University Press.

Schaffner, I. (2002) Salvador Dali's Dream of Venus: The Surrealist Funhouse from the 1939 World's Fair. New York: Princeton Architectural Press.

Sharman, T. (2005) Catalogue entry on Bacchanale designs in Ades, D. (ed.) Dali: The Centenary. London: Thames and Hudson, pp. 316-18.

Unknown author, (1939) 'Music: Krafft-Ebing Follies’ Time, (20 November).

Unknown author (undated), cutting from an unknown magazine, Leonor Fini Archive, Paris. Wagner, R. (1988) ‘Tannhäuser’ in Nicholas, J. (ed.) Tannhäuser, Opera Guide Series number 39, ed. Nicholas John. London: John Calder; New York: Riverrun Press, English National Opera and Royal Opera, pp. 60-93.

\footnotetext{
${ }^{1}$ Images of the Bacchanale set design can be found online; it features on websites dedicated to Dalí's paintings and multiple other websites offer art prints of it.

${ }^{2}$ Valentina Vacca has published two excellent articles in Italian on Fini's theatrical and fancy-dress costumes in the 2014 and 2017 volumes of Memoria e materia dell'opera d'arte
} 
(Rome: Gangemi Editore and Università Tuscia). There is also a short exhibition catalogue on Fini's designs produced by the CFM Gallery, New York in 1992.

${ }^{3}$ Overlaps between Fini's painting, design, and personal life are common in her oeuvre. I explore some of the overlaps between her fancy-dress costumes, ballet costumes, and painting in my essay "Flowers, feathers, and flux: Artifice in the costumes of Leonor Fini" in Patricia Allmer (ed.) Intersections: Women/Surrealism/Modernism (Manchester: Manchester University Press, 2016), pp. 259-74.

Rachael Grew is a Lecturer in art history and visual culture at Loughborough University. Her research explores bodily manifestations of gender, hybridity, and fluid identities, particularly in the work of Leonor Fini. She has published a range of essays and articles on Fini's scenographic designs, as well as on gender issues within Surrealism more broadly. Rachael is currently working towards a monograph on Fini's use of repested motifs across the various aspects of her oeuvre.

r.v.grew@1boro.ac.uk

Martin Hall, Loughborough University, Epinal Way, Loughborough, Leicestershire, LE11 3TU, UK. 